\title{
Skeletal Muscle and Peripheral Nerve Histopathology in COVID-19
}

Joome Suh, MD, Shibani S. Mukerji, MD, PhD, Sarah I. Collens, BS, Robert F. Padera, Jr., MD, PhD, Geraldine S. Pinkus, MD, Anthony A. Amato, MD,* and Isaac H. Solomon, MD, PhD*

Neurology ${ }^{\circledR}$ 2021;97:e849-e858. doi:10.1212/WNL.0000000000012344

\section{Abstract}

\section{Objective}

To explore the spectrum of skeletal muscle and nerve pathology of patients who died after severe acute respiratory syndrome coronavirus 2 (SARS-CoV-2) infection and to assess for direct viral invasion of these tissues.

\section{Methods}

Psoas muscle and femoral nerve sampled from 35 consecutive autopsies of patients who died after SARS-CoV-2 infection and 10 SARS-CoV-2-negative controls were examined under light microscopy. Clinical and laboratory data were obtained by chart review.

\section{Results}

In SARS-CoV-2-positive patients, mean age at death was 67.8 years (range 43-96 years), and the duration of symptom onset to death ranged from 1 to 49 days. Four patients had neuromuscular symptoms. Peak creatine kinase was elevated in 74\% (mean 959 U/L, range 29-8,413 $\mathrm{U} / \mathrm{L}$ ). Muscle showed type 2 atrophy in 32 patients, necrotizing myopathy in 9, and myositis in 7. Neuritis was seen in 9. Major histocompatibility complex-1 (MHC-1) expression was observed in all cases of necrotizing myopathy and myositis and in 8 additional patients. Abnormal expression of myxovirus resistance protein $\mathrm{A}(\mathrm{MxA})$ was present on capillaries in muscle in 9 patients and in nerve in 7 patients. SARS-CoV-2 immunohistochemistry was negative in muscle and nerve in all patients. In the 10 controls, muscle showed type 2 atrophy in all patients, necrotic muscle fibers in 1, MHC-1 expression in nonnecrotic/nonregenerating fibers in 3, MxA expression on capillaries in 2, and inflammatory cells in none, and nerves showed no inflammatory cells or MxA expression.

\section{Conclusions}

Muscle and nerve tissue demonstrated inflammatory/immune-mediated damage likely related to release of cytokines. There was no evidence of direct SARS-CoV-2 invasion of these tissues.

\section{Classification of Evidence}

This study provides Class IV evidence that muscle and nerve biopsies document a variety of pathologic changes in patients dying of coronavirus disease 2019 (COVID-19).

\author{
Correspondence \\ Dr. Solomon \\ insolomon@ \\ bwh.harvard.edu \\ or Dr. Amato \\ aamato@bwh.harvard.edu
}

MORE ONLINE

COVID-19 Resources

For the latest articles, invited commentaries, and blogs from physicians around the world NPub.org/COVID19

\section{Class of Evidence} Criteria for rating therapeutic and diagnostic studies

NPub.org/coe

\section{CME Course}

NPub.org/cmelist

\footnotetext{
*These authors contributed equally to this work.
}

From the Departments of Neurology (J.S., A.A.A.) and Pathology (R.F.P., G.S.P., I.H.S.), Brigham and Women's Hospital; Harvard Medical School (J.S., S.S.M., R.F.P., G.S.P., A.A.A., I.H.S.); and Department of Neurology (S.S.M., S.I.C.), Massachusetts General Hospital, Boston.

Go to Neurology.org/N for full disclosures. Funding information and disclosures deemed relevant by the authors, if any, are provided at the end of the article. 


\section{Glossary}

CK = creatine kinase; COVID-19 = coronavirus disease 2019; IHC = immunohistochemistry; MHC-1 = major histocompatibility complex-1; MxA = myxovirus resistance protein A; RT-PCR = reverse-transcriptase PCR; SARS-CoV = severe acute respiratory syndrome coronavirus; $\mathbf{W B C}=$ white blood cell.

Severe acute respiratory syndrome coronavirus 2 (SARS-CoV2 ) infection is associated with myalgia or fatigue in $11 \%$ to $70 \%$ of individuals and elevated creatine kinase (CK) elevation in $9 \%$ to $33 \% .{ }^{1-7}$ Rhabdomyolysis and myositis have been reported, ${ }^{8-12}$ but only a few studies included muscle biopsies, ${ }^{13-15}$ and it is unclear whether muscle damage is the result of viral infection of muscle, toxic effect of cytokines, or another mechanism. In addition, Guillain-Barre syndrome and variants have been described, but studies reporting nerve histopathology are lacking. ${ }^{1,16-21}$ We report histopathologic findings in skeletal muscle and peripheral nerve from 35 consecutive autopsies performed on patients with coronavirus disease 2019 (COVID19) who died between April 5, 2020, and June 13, 2020.

\section{Methods}

\section{Patient Cohort}

All patients with SARS-CoV-2 infection who died between April 5, 2020, and June 13, 2020, and subsequently underwent autopsy at Brigham and Women's Hospital were included in this study. Informed consent for autopsy was obtained from next of kin or health care proxy of the deceased. Thirty-three patients were diagnosed by positive premortem or perimortem reversetranscriptase PCR (RT-PCR) of nasopharyngeal swabs, and 2 patients were diagnosed by the presence of SARS-CoV-2 immunoglobulin $\mathrm{M}$ or $\mathrm{G}$ antibodies (patients 25 and 35). In addition, 10 patients who were negative for SARS-CoV-2 but were critically ill and died during the COVID-19 pandemic were included as negative controls. Patient demographics, clinical data, and laboratory data were extracted from the electronic medical record when available.

\section{Standard Protocol Approvals, Registrations, and Patient Consents}

This study was approved by the Mass General Brigham Human Research Committee on an excess tissue waived consent protocol.

\section{Muscle and Nerve Pathology}

Autopsies were performed in a negative-pressure isolation room by personnel equipped with powered air-purifying or N95 respirators. Samples of psoas muscle and femoral nerve were collected for each patient, and tissue was fixed in $10 \%$ formalin before standard processing and paraffin embedding. Fivemicron-thick sections of psoas muscle were stained with (1) hematoxylin \& eosin, (2) Masson trichrome (Agilent Artisan AR173, Santa Clara, CA), (3) anti-myosin (skeletal, fast) antibody (Sigma M4276, 1:10,000 dilution, St. Louis, MO), (4) antiLCA/CD45 antibody (Dako M0701, 1:600 dilution, Glostrup,
Denmark), (5) anti-SARS-CoV nucleocapsid antibody (Novus Biologicals NB100-56576, 1:500 dilution, Littleton, CO), (6) anti-HLA class $1 \mathrm{ABC} /$ major histocompatibility-1 (MHC-1) antibody (Abcam ab70328, 1:15,000 dilution, Cambridge, UK; Leica BOND III immunostainer, antigen retrieval with ER2 and Leica Bond Polymer Refine Detection, Newcastle, UK), and (7) anti-human myxovirus resistance protein $\mathrm{A}(\mathrm{MxA})$ antibody (Millipore M143, 1:50 dilution, Burlington, MA; heat-induced epitope retrieval, horseradish peroxidase-conjugated polymeric goat anti-rabbit immunoglobulin antibody, and DAB chromogen). Femoral nerve sections were stained with (1) hematoxylin \& eosin, (2) Masson trichrome, (3) anti-LCA/CD45 antibody, (4) anti-SARS-CoV nucleocapsid antibody, and (5) anti-MxA antibody. Muscle and nerve sections from cases with increased CD45-positive immune infiltrates were also stained with (1) anti-CD4 antibody (Cell Marque EP204, 1:100 dilution, Rocklin, CA), (2) anti-CD8 antibody (Dako CD8/144D, 1:200 dilution), (3) anti-CD20 antibody (Dako L26, 1:250 dilution), and (4) anti-CD68 antibody (Dako PG-M1, 1:200 dilution). Slides were reviewed independently by a board-certified neuropathologist (I.H.S.) and a neurologist board certified in neuromuscular medicine and clinical neuromuscular pathology (A.A.A.).

\section{Statistics}

Categorical variables are presented as number (percent). Continuous variables are summarized as mean (range). Statistical comparisons were not performed due to small sample size in each group.

\section{Data Availability}

Additional data (tables e-1 and e-2) are available from Dryad (doi.org/10.5061/dryad.wwpzgmsjj). Fully anonymized data will be shared by request from any qualified investigator.

\section{Classification of Evidence}

The primary research question of this study was to evaluate the effects of SARS-CoV-2 infection on skeletal muscle and peripheral nerve in patients who died with COVID-19, confirmed by nasopharyngeal swab RT-PCR or serology. This study provides Class IV evidence that muscle and nerve tissue exhibits inflammatory/immune-mediated damage likely related to release of cytokines in the absence of direct SARS$\mathrm{CoV}-2$ invasion of these tissues.

\section{Results}

\section{Clinical Features}

Patient demographics, neuromuscular symptoms, and pertinent home and inpatient medications that may affect muscle 
Table 1 Demographics and Clinical History in COVID-19 Decedents and COVID-19-Negative Controls

\begin{tabular}{|c|c|c|}
\hline & $\begin{array}{l}\text { COVID-19-Positive } \\
\text { Patients }(n=35)\end{array}$ & $\begin{array}{l}\text { COVID-19-Negative } \\
\text { Controls }(n=10)\end{array}$ \\
\hline $\begin{array}{l}\text { Mean age at death } \\
\text { (range), y }\end{array}$ & $67.8(43-96)$ & $71.3(54-84)$ \\
\hline Female sex, $\mathrm{n}(\%)$ & $12(34.2)$ & $6(60)$ \\
\hline \multicolumn{3}{|l|}{ Medical history, n (\%) } \\
\hline $\begin{array}{l}\text { Connective tissue } \\
\text { disease }\end{array}$ & $3(8.6)$ & 0 \\
\hline Diabetes & $17(48.6)$ & $1(10)$ \\
\hline CKD & $7(20)$ & $1(10)$ \\
\hline Polyneuropathy & $2(5.7)$ & 0 \\
\hline Cancer & $6(17.1)$ & $4(40)$ \\
\hline \multicolumn{3}{|l|}{$\begin{array}{l}\text { Home medications, } \\
\text { n (\%) }\end{array}$} \\
\hline Statin & $11 / 26(42.3)$ & 4/9 (44.4) \\
\hline Steroid & $2 / 26(7.7)$ & $2 / 9(22.2)$ \\
\hline Colchicine & $1 / 26(3.8)$ & 0 \\
\hline Chemotherapy & $1 / 26(3.8)$ & $1 / 9(11.1)$ \\
\hline $\begin{array}{l}\text { Immune checkpoint } \\
\text { inhibitor }\end{array}$ & $1 / 26(3.8)$ & $1 / 9(11.1)$ \\
\hline \multicolumn{3}{|l|}{$\begin{array}{l}\text { Inpatient medications } \\
\text { for COVID-19, } n(\%)\end{array}$} \\
\hline Remdesivir & $5(14.3)$ & NA \\
\hline Tocilizumab & $5(14.3)$ & NA \\
\hline Hydroxychloroquine & 4 or $5(11.4 \text { or } 14.3)^{b}$ & NA \\
\hline $\begin{array}{l}\text { Neuromuscular } \\
\text { symptoms, n (\%) }\end{array}$ & 4/35 (11.4) & $3 / 10(30)$ \\
\hline
\end{tabular}

Abbreviations: CKD = chronic kidney disease; COVID-19 = coronavirus disease 2019; NA = not applicable.

a Denominator denotes total number of patients for whom premortem home medications were known.

${ }^{\mathrm{b}}$ One patient was enrolled in hydroxychloroquine vs placebo trial.

or peripheral nerve histopathology are presented in table 1 (details for individual patients are provided in table e-1, doi. org/10.5061/dryad.wwpzgmsjj). Twelve of 35 patients (34\%) were women and $23(66 \%)$ were men. Mean age at death was 67.8 years (range $43-96$ years). Time from symptom onset to death ranged from 1 to 49 days, and time from positive SARSCoV-2 RT-PCR test to death was $<1$ to 44 days. Four patients complained of myalgia or weakness in arms and legs. Diabetes and connective tissue disease were present in 17 and 3 patients, respectively. Of 26 patients with known premortem home medications, 11 patients were on statins, 2 were on corticosteroids (patients 1 and 6), 1 (patient 25) was on imatinib for gastrointestinal stromal tumor, 1 (patient 27) was on colchicine, and 1 (patient 32) was on pembrolizumab for squamous cell lung cancer. Five patients received tocilizumab; 5 received remdesivir; and 4 or 5 received hydroxychloroquine (1 patient was in a placebo-controlled trial) during hospitalization for COVID-19. One patient received dexamethasone (patient 6) but not specifically for COVID-19. Characteristics of the 10 COVID-19-negative control patients are also shown in table 1 and table e-1. There were no major differences compared to the COVID-19-positive cohort except for a lower prevalence of diabetes in the control group. Three patients in the control group (patients C1, C3, and C5) had neuromuscular complaints of generalized weakness.

\section{Laboratory Data}

Twenty-seven of 35 patients with COVID-19 had CK values available from the hospitalization before death (table e-2, doi. org/10.5061/dryad.wwpzgmsji). Of these, 20 patients (74\%) had elevated peak $\mathrm{CK}$ with a mean of $959 \mathrm{U} / \mathrm{L}$ and range of 29 to 8,413 U/L (normal 39-308 U/L for men and 26-192 U/L for women). Nineteen patients had repeat CKs, 9 of which were still elevated before death. Sixteen of the 20 patients also had elevated peak high-sensitivity troponin $\mathrm{T}$ levels, of whom 3 had evidence of acute cardiac injury on pathologic examination (patients 1,24, and 30). Peak white blood cell (WBC) count was elevated in 20 of $27(74 \%)$ patients with a mean of $18.9 \times 10^{3} / \mu \mathrm{L}$ and range of 1.7 to $64.9 \times 10^{3} / \mu \mathrm{L}\left(\right.$ normal $\left.4-10 \times 10^{3} / \mu \mathrm{L}\right)$. Peak C-reactive protein was elevated in all 25 patients measured, with a mean of $154 \mathrm{mg} / \mathrm{L}$ and range of 6 to $>300 \mathrm{mg} / \mathrm{L}$ (normal 0-3 mg/L). In the control patients, peak $\mathrm{CK}$ was available in only 2 patients (patients C9 and C10) and was elevated at 1,746 and 1,152 U/L, respectively. Peak WBC count was elevated in all 8 patients with available $\mathrm{WBC}$ counts, with a mean of $22.1 \times 10^{3} / \mu \mathrm{L}$ and range of 11.8 to $43.3 \times 10^{3} / \mu \mathrm{L}$.

\section{Muscle Histopathology}

Microscopic examination of muscle (figure 1 and table 2) showed type 2 fiber atrophy in 32 of 35 patients with COVID19 , a necrotizing myopathy in 9 (no inflammatory cells aside from myophagocytosis of necrotic fibers), and myositis in 7 (defined by perivascular and endomysial inflammatory cell infiltrates). In patients with myositis, CD68-positive, CD4-positive, and/or CD8-positive histiocytes and T cells were observed more frequently than CD20-positive B cells. Diffuse or multifocal MHC-1 immunostaining of nonnecrotic/nonregenerating muscle fibers was evident in all 16 patients with myositis or necrotizing myopathy and in 8 additional patients. One patient (patient 35) exhibited MHC-1 staining predominantly in perifascicular muscle fibers, a finding often seen in dermatomyositis; however, there was no abnormal MxA expression or documentation of clinical features suggestive of dermatomyositis. Abnormal MxA immunostaining was observed in 4 of 9 patients with necrotizing myopathy, 3 of 7 with myositis, and 2 without either. Of these 9 patients, MxA was observed only in the capillaries in 8 and in both myocytes and capillaries in 1 patient. SARS-CoV-2 nucleocapsid immunohistochemistry (IHC) was negative in all 35 cases.

In the 10 control patients, all of whom had multiple medical comorbid conditions, type 2 atrophy was observed in all 


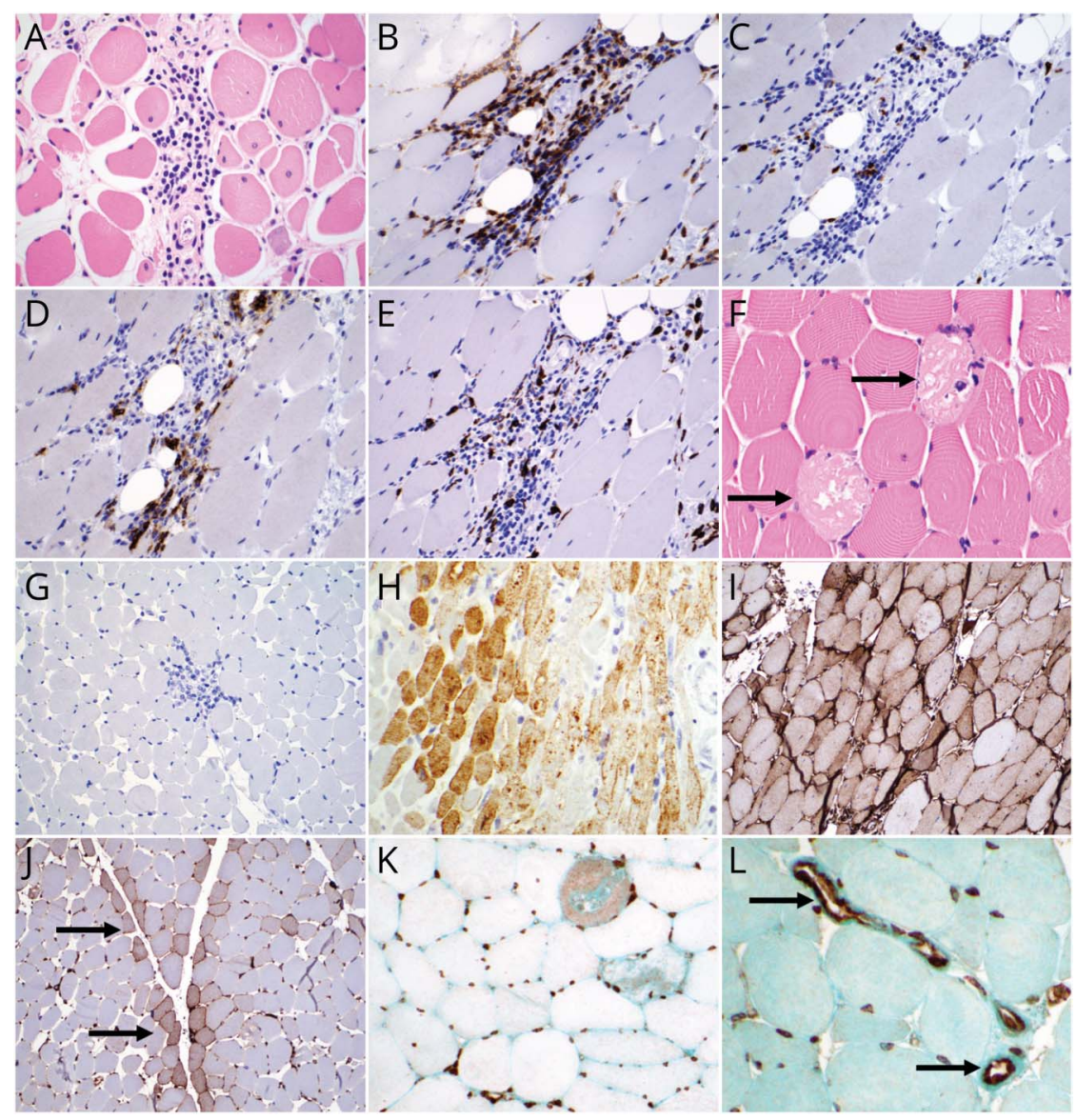

Histologic findings in psoas muscle include (A) perivascular and endomysial inflammation, made up of mixed (B) CD4, (C) CD8, (D) CD20, and (E) CD68 immune infiltrates, as well as (F) occasional necrotic fibers (arrows). (G) Severe acute respiratory syndrome coronavirus 2 (SARS-CoV-2) immunohistochemistry (IHC) was negative in skeletal muscle for all patients. (H) Positive control for SARS-CoV-2 IHC shows sarcoplasmic staining in cardiac myocytes. Major histocompatibility complex-1 (MHC-1) IHC reveals variable sarcolemmal and sarcoplasmic staining patterns, including (I) diffuse and (J) perifascicular distributions (arrows). Human myxovirus resistance protein $\mathrm{A}(\mathrm{M} \times \mathrm{A}) \mathrm{IHC}$ highlights $(K)$ rare necrotic fibers and $(L)$ scattered capillary cell walls (arrows). Panels A-E and I are from patient 1; panels $\mathrm{F}$ and $\mathrm{K}$ are from patient 2 ; panel $\mathrm{H}$ is from patient 6 ; panels $\mathrm{G}$ and $\mathrm{L}$ are from patient 25; and panel $\mathrm{J}$ is from patient 35 . Panels $\mathrm{A}$ and $\mathrm{F}$ were stained with hematoxylin \& eosin; panel $B$ was stained with CD4 IHC; panel C was stained with $\mathrm{CD} 8 \mathrm{IHC}$; panel D was stained with CD20 IHC; panel E was stained with CD68 IHC; panels $\mathrm{G}$ and $\mathrm{H}$ were stained with SARS-CoV-2 nucleocapsid IHC; panels I and I were stained with MHC-1 IHC; and panels $K$ and L were stained with MxA IHC. Images from panel I and J taken with $\times 20$ objective, from panels $\mathrm{A}-\mathrm{H}$ with $\times 40$ objective, and from panels $K$ and $L$ with $\times 60$ objective.

patients. One patient (patient $\mathrm{C} 4$ ) had rare necrotic muscle fibers that expressed MHC-1 and MxA; this patient did not have a history of statin use, use of drugs with potential myotoxicity, or cancer. Myositis was not observed in any patients. MHC-1 immunostaining of nonnecrotic/nonregenerating fibers was seen in 3 patients (patients $\mathrm{C} 1, \mathrm{C} 5$, and $\mathrm{C} 8$ ), and $\mathrm{MxA}$ immunostaining was seen in 1 patient (patient C8), in addition to patient $\mathrm{C} 4$ mentioned above. None of these patients had a documented history of myopathy or connective tissue disease.

Potential associations between histopathologic findings in muscle and medical history were reviewed for COVID-19positive patients (figure 2). Three of the 9 patients with necrotizing myopathy took statins premortem (patients 4,10 , and 17), which was similar to the proportion of patients without necrotizing myopathy who took statins ( 8 of 26 patients). However, medication history was not known in 5 of 9 with necrotizing myopathy and in 4 of 26 without necrotizing myopathy. Nevertheless, myotoxicity related to statins and other medications would not be expected to show MHC-1 expression in nonregenerating, nonnecrotic muscle fibers or MxA expression in capillaries. Two of the 7 patients with myositis (patients 1 and 25) and 1 of the 28 patients without myositis (patient 20) had an underlying connective tissue disease. One patient with myositis (patient 32) received 2 cycles of an immune checkpoint inhibitor (pembrolizumab) in the 2 months preceding death. However, none of these patients had a documented history of myopathy associated with these conditions or medication use.

Mean time from onset of COVID-19 symptoms to death was 12.8 days in patients with necrotizing myopathy, 17.1 days in patients with myositis, and 18.1 days in those with neither finding. Statistical comparisons were not performed due to small sample size in each group. Peak WBC count (available in 27 patients) was elevated in 5 of 7 patients (71\%) with necrotizing myopathy, 4 of 5 patients $(80 \%)$ with myositis, and 11 of 15 patients $(73 \%)$ without either finding. Peak CK was elevated in 10 of 12 patients (83\%) with myositis or necrotizing myopathy and laboratory results. Peak CK was also elevated in 10 of 15 patients (67\%) without these histopathologic findings, 5 of whom were MHC-1 positive. Associations are best seen in figure 2 .

\section{Nerve Histopathology}

Microscopic examination of nerve showed neuritis in 9 patients (figure 3 and table 2), of whom 4 also had myositis (patients 24, 25, 32, 35). Perivascular inflammatory cells were 
Table 2 Muscle and Nerve Histopathology

\begin{tabular}{|c|c|c|}
\hline & $\begin{array}{l}\text { COVID-19-Positive } \\
\text { Patients }(n=35)\end{array}$ & $\begin{array}{l}\text { COVID-19-Negative } \\
\text { Controls }(n=10)\end{array}$ \\
\hline \multicolumn{3}{|c|}{$\begin{array}{l}\text { Psoas muscle } \\
\text { histopathology, n (\%) }\end{array}$} \\
\hline Type 2 atrophy & $32(91.4)$ & $10(100)$ \\
\hline $\begin{array}{l}\text { Necrotic fibers } \\
\text { without } \\
\text { inflammation }\end{array}$ & $9(25.7)$ & $1(10)$ \\
\hline $\begin{array}{l}\text { Inflammation } \pm \\
\text { necrotic fibers }\end{array}$ & $7(20)$ & 0 \\
\hline MHC-1 IHC ${ }^{a}$ & $24(68.6)$ & $3(30)$ \\
\hline $\begin{array}{l}\text { MxA IHC (of } \\
\text { capillaries or } \\
\text { myocytes) }\end{array}$ & $9(25.7)$ & $2(20)$ \\
\hline SARS-CoV-2 IHC & 0 & NA \\
\hline \multicolumn{3}{|c|}{$\begin{array}{l}\text { Femoral nerve } \\
\text { histopathology, n (\%) }\end{array}$} \\
\hline Inflammation & $9(25.7)$ & 0 \\
\hline $\begin{array}{l}\text { MxA IHC (of } \\
\text { capillaries) }\end{array}$ & $7(20)$ & 0 \\
\hline SARS-CoV-2 IHC & 0 & NA \\
\hline \multicolumn{3}{|c|}{$\begin{array}{l}\text { Abbreviations: COVID-19= coronavirus disease 2019; IHC = immunohisto- } \\
\text { chemistry; MHC-1 = major histocompatibility complex } 1 ; \mathrm{M} \times \mathrm{A}=\text { human } \\
\text { myxovirus resistance protein A; NA = not applicable; SARS-CoV-2 = severe } \\
\text { acute respiratory syndrome coronavirus } 2 \text {. } \\
\text { a In nonnecrotic, nonregenerating fibers. }\end{array}$} \\
\hline
\end{tabular}

observed in 6 patients, endoneurial infiltrates in 1, and both perivascular and endoneurial inflammatory cells in 2. CD68positive histiocytes were most abundantly observed in all cases but were sometimes copredominant with CD8-positive or, less often, CD4-positive T cells. MxA immunostaining was observed in 7 of 35 (20\%) of cases in the capillaries, only 1 of whom had neuritis. SARS-CoV-2 IHC was negative in all 35 cases. Neither inflammatory cell infiltrates nor abnormal MxA expression was observed in the control cases.

Review of medical history for conditions associated with neuritis revealed a history of diabetes in 4 of 9 patients (44\%) with neuritis (patients $3,15,23,24)$ and in 13 of $26(50 \%)$ without neuritis (table 1 and figure 2). History of connective tissue disease was present in 2 patients with neuritis (patients 20,25 ) and in 1 without neuritis. One patient with neuritis received pembrolizumab (patient 32); this patient also had myositis, as mentioned above. Of 35 patients, only 2 (patients 6,23 ) had a history of polyneuropathy predating SARS-CoV2 infection. One (patient 6) had a history of diabetes and received chemotherapy (including vincristine) for acute lymphoblastic leukemia but had no inflammation on nerve examination. The other (patient 23) had diabetes and neuritis on histopathology. Mean time from onset of COVID-19 symptoms to death was 13.4 days in patients with neuritis and 17.6 days in patients without neuritis. Peak WBC count was elevated in all 6 patients with neuritis and 14 additional patients (of 27 patients with available laboratory values).

\section{COVID-19 Therapies}

Twelve patients received tocilizumab, hydroxychloroquine, or remdesivir during hospitalization for COVID-19. While formal statistical analyses were not performed, use of these medications did not appear to be associated with specific histopathologic features in muscle or nerve. Myositis was seen in 1 patient who took tocilizumab (patient 1 ) and 1 patient who took tocilizumab plus remdesivir (patient 12). Necrotizing myopathy was seen in 1 patient who took hydroxychloroquine (patient 4) and 1 patient who took hydroxychloroquine plus tocilizumab (patient 10). Neuritis was seen in 1 patient who took tocilizumab (patient 26).

\section{Neuromuscular Symptoms}

Documentation of neuromuscular symptoms or examination during hospitalization for SARS-CoV-2 infection was lacking for most patients. Nonspecific fatigue was not included as a neuromuscular symptom in this study. Four patients had myalgia or subjective weakness affecting arms and legs (patients 4, $10,14,16)$. These 4 patients had type 2 fiber atrophy, necrotic myocytes, and MHC-1 immunostaining on nonnecrotic/ nonregenerating muscle fibers. Peak CK levels were elevated at 488 to 2,806 U/L. Nerve histopathology was normal in these 4 patients.

\section{Discussion}

The pathophysiology of SARS-CoV-2-associated myopathy is poorly understood. The possibility of skeletal muscle infection by the virus has been considered because muscle expresses angiotensin-converting enzyme 2, which is a cell surface receptor used by SARS-CoV-1 and SARS-CoV-2 for host cell entry. ${ }^{22,23}$ Negative SARS-CoV-2 IHC in muscle in our study argues against this hypothesis. However, in 1 study that examined the diaphragm muscle obtained from 26 consecutive autopsies of critically ill COVID-19-infected patients who died, SARS-CoV-2 RNA was found in the muscle in 4 cases (15.4\%). ${ }^{24}$ In situ hybridization localized the RNA to inside the sarcolemma. This discrepancy with our study findings may be explained by differences in methods to detect the virus or examination of different muscles.

Twenty-four of 35 patients in our study had evidence of an inflammatory or immune-mediated myopathy with necrotic fibers, inflammatory cell infiltrates, or MHC-1 immunostaining of nonnecrotic/nonregenerating muscle fibers. Our observations suggest that muscle damage occurs secondary to an inflammatory response, including damage from cytokines.

To date, literature on skeletal muscle histopathology in COVID-19 is sparse. One study reported muscle biopsy findings in 3 patients infected with SARS-CoV-2 who were 


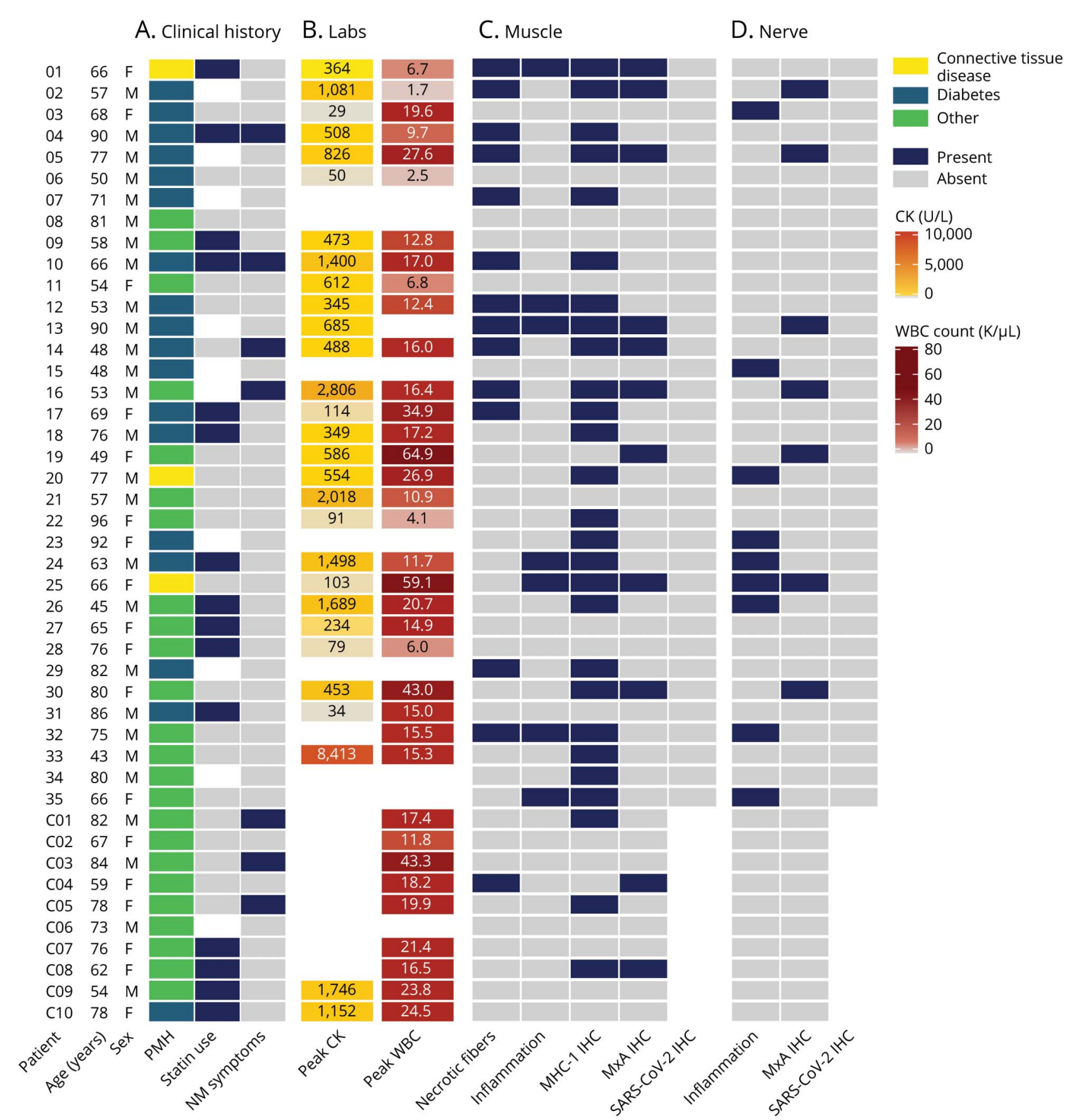

Heat map showing (A) clinical findings from 35 coronavirus disease 2019 (COVID-19)-positive patients (patients 1-35) and 10 COVID-19-negative control patients (patients (1-C10), including age, sex, relevant medical history (PMH), statin use, and neuromuscular symptoms during hospitalization, and (B) laboratory values for peak creatine kinase (CK) and white blood cell count (WBC). Heat map showing major histopathologic findings in (C) skeletal muscle and (D) peripheral nerve, including presence of necrotic fibers, inflammation assayed by anti-LCA/CD45 immunohistochemistry (IHC), major histocompatibility complex-1 (MHC-1) IHC, human myxovirus resistance protein A (MxA) IHC, and severe acute respiratory syndrome coronavirus 2 (SARS-CoV-2) nucleocapsid protein IHC (right). White boxes indicate data not available. NM = neuromuscular.

clinically suspected of having critical illness myopathy. ${ }^{25}$ Biopsies revealed scattered necrotic and regenerating fibers in 1 patient and rare atrophic and regenerative fibers in 2 others. No biopsies stained positive for MHC-1 or membrane attack complex (C5b9). In these patients, the histopathologic findings likely reflected the clinically suspected critical illness myopathy rather than COVID-19-associated myopathy.
Myositis was reported in a 58-year-old patient with SARSCoV-2 infection with facial weakness, nasal dysarthria, and dysphagia. ${ }^{13}$ Muscle biopsy showed perivascular and endomysial inflammation and MHC-1 expression. The patient had a dermatomyositis-specific autoantibody detected in the serum. Viral invasion of muscle was not seen on electron microscopy. Another autopsy series reported myositis in 2 of 10 


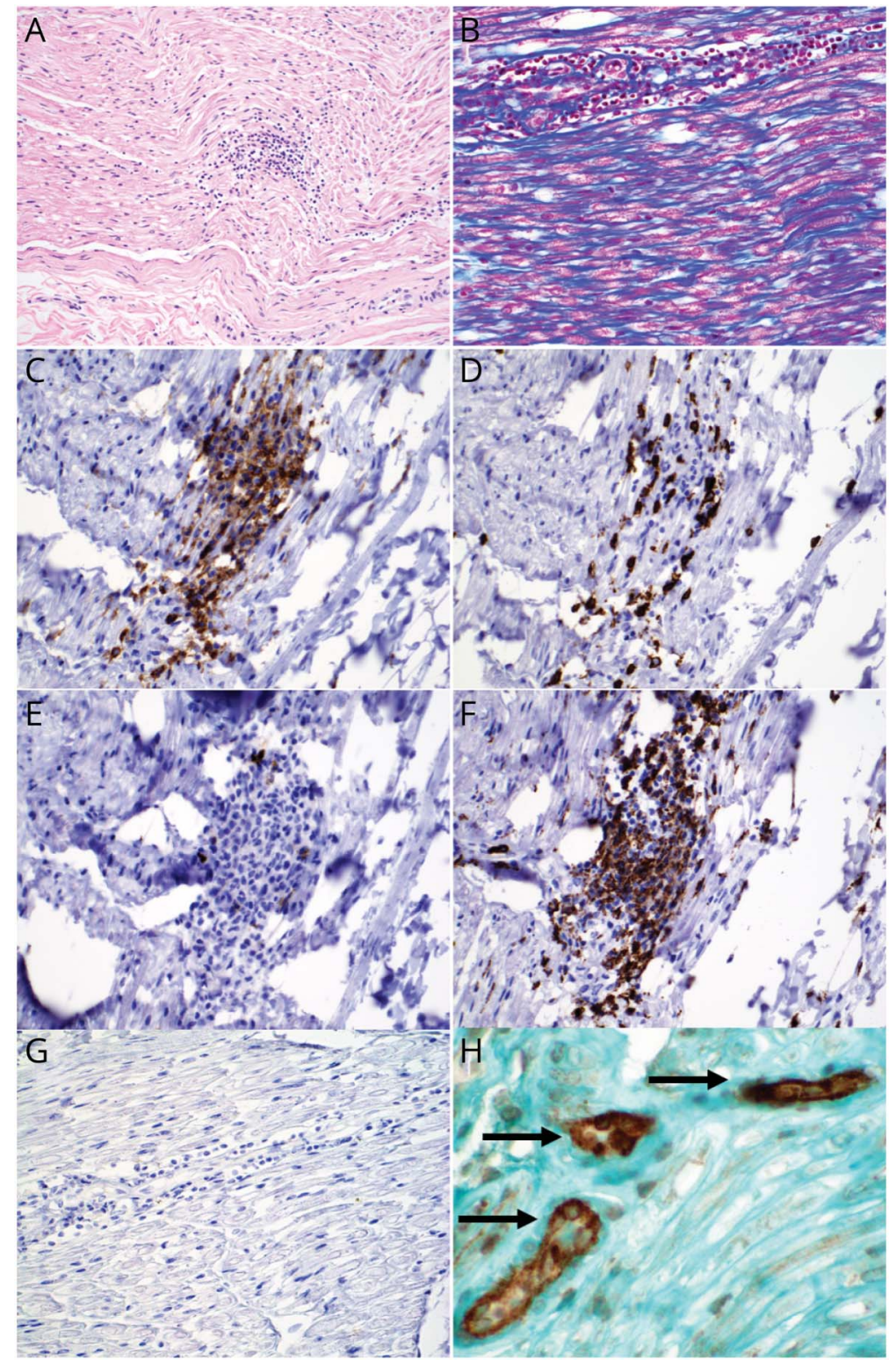

Histologic findings include (A) perivascular and endoneurial inflammation, in the absence of (B) demyelination, comprising mixed (C) CD4, (D) CD8, (E) CD20, and (F) CD68 immune cell infiltrates. (G) Severe acute respiratory syndrome coronavirus 2 (SARS-CoV-2) immunohistochemistry (IHC) was negative in all cases. (H) Human myxovirus resistance protein A (MXA) IHC highlights scattered capillary cell walls (arrows). Panel $\mathrm{H}$ is from patient 19; panels $\mathrm{B}$ and $\mathrm{G}$ are from patient 20; panel A is from patient 25; and panels C-F are from patient 26. Section from panel A stained with hematoxylin and eosin, panel B with Masson trichrome, panel C with CD4 IHC, panel D with $\mathrm{CD} 8 \mathrm{IHC}$, panel $\mathrm{E}$ with $\mathrm{CD} 20 \mathrm{IHC}$, panel $\mathrm{F}$ with CD68 IHC, panel G with SARS-CoV-2 nucleocapsid IHC, and panel $\mathrm{H}$ with $\mathrm{MxA} I \mathrm{HC}$. Image in panel A taken with $\times 20$ objective; images in panels $B-G$ with $\times 40$ objective; and images in panel $\mathrm{H}$ with $\times 60$ objective.

autopsies, but it is unclear how myositis was defined. ${ }^{14} \mathrm{~A}$ figure showed necrotic fibers undergoing myophagocytosis in 1 patient. We recently reported a patient with marked weakness and elevated CK (up to 30,000 U/L) who had overexpression of MHC-1 and MxA on perifascicular muscle fibers and capillaries, suggestive of a type-1 interferonopathy. ${ }^{15}$ One patient in our autopsy series (patient 35) also had MHC-1 expression on perifascicular muscle fibers but without MxA expression.

How do our findings compare to myopathy associated with other coronavirus infections? In a small post-mortem series of patients who died of SARS-CoV-1 infection, myofiber atrophy and necrosis were also the most common histopathologic findings in skeletal muscle. ${ }^{26} \mathrm{MHC}-1$ and MxA staining was not performed. Findings were thought to reflect critical illness myopathy or specific changes of SARS-CoV-1-associated myopathy. Another series found vasculitis in muscle. ${ }^{27}$ The virus was not detected in muscle with methods of viral culture, electron microscopy, IHC, or in situ hybridization. ${ }^{26,28}$ One postmortem case report on a patient with cutaneous $\mathrm{T}$-cell lymphoma and Middle East respiratory syndrome coronavirus showed necrotic fibers and an inflammatory infiltrate made up of CD68-positive histiocytes and mixed CD4-positive and CD8-positive $\mathrm{T}$ cells. ${ }^{29}$ Electron microscopy identified viruslike particles in macrophages infiltrating muscle but not in muscle fibers.

In nerve biopsies, we found perivascular and endoneurial inflammatory cell infiltrates (neuritis) in 9 patients. History of 
diabetes was present in 4 patients, connective tissue disease in 2 , and immune checkpoint inhibitor use in 1 , conditions in which neuritis can be seen. ${ }^{30,31}$ None had signs or symptoms of Guillain-Barre syndrome. We cannot exclude these conditions as potential etiologies of the observed neuritis (e.g., diabetic lumbosacral radiculoplexus neuropathy or diabetic amyotrophy), although we think these are unlikely to be coincidental occurrence in the patients with inflammatory cell infiltrates in their nerves and MxA expression on capillaries, which would not be seen in these disorders. SARS-CoV-2 was not found in our nerve biopsies by IHC, suggesting that the virus does not infect peripheral nerve.

In contrast to our findings, a CNS-focused postmortem series reported SARS-CoV-2 immunostaining in cranial nerves (glossopharyngeal and vagal nerves), albeit in only 2 of 40 patients, raising the possibility that viral infection of peripheral nerve may occur. ${ }^{32}$ In that study, SARS-CoV-2 immunostaining was found in undefined cells within the medulla from which these cranial nerves originate. Contiguous spread of infection from the medulla to these cranial nerves is conceivable.

It is possible that viral invasion of muscle and nerve occurred at an earlier stage in the illness and that active viral infection resolved by the time of death, although 22 patients (63\%) had detectable SARS-CoV-2 in the lower respiratory tract by IHC, suggesting ongoing infection in other tissues. Viral RNA may be cleared from muscle and nerve tissue due to efficient type 1 interferon response (e.g., including $\mathrm{MxA}$ expression) or other mechanisms but not be cleared from more highly burdened organs such as the lungs.

Notably, MxA expression was observed in endothelial cells in 9 of 35 muscle and 7 of 35 nerve biopsies in our autopsy series, which is likely the result of the host response to SARS-CoV-2 infection. MxA is a type 1 interferon-inducible protein that is normally expressed in response to viral infections and prevents viral replication in the host. However, overexpression of type 1 interferons can be toxic, and abnormal expression of $\mathrm{MxA}$ in various tissues is seen in type 1 interferonopathies, including dermatomyositis, systemic lupus erythematosus, and idiopathic pernio (chilblains). As mentioned, we previously reported a patient with COVID-19-associated myopathy who had overexpression of MxA on perifascicular muscle fibers and capillaries, as typical of dermatomyositis and suggestive of a type 1 interferonopathy. ${ }^{15}$ Perniosis with MxA expression in endothelial cells and surrounding dermal and epidermal tissues has been reported in children and young adults late in the course of mild confirmed or presumed COVID-19 infection. ${ }^{33,34}$ It is speculated that efficient induction of type 1 interferons and activation of the innate immune system quickly eradicate the virus and result in a mild infection but may cause collateral tissue damage. In critically ill patients, similar acral manifestations can occur due to severe thrombotic retiform purpura, in which abnormal MxA expression is not seen. ${ }^{34}$ Such cases could represent an insufficient type 1 interferon response to the virus. These studies suggest that the type 1 interferon response is protective in viral infection, but overexpression may be toxic to certain tissues. Peripheral nerve and skeletal muscle appear to be bystander victims of the host response and cytokine dysregulation. We suspect that an exaggerated type 1 interferon response might be involved in some cases of COVID-19associated myopathy and neuropathy. However, the lack of consistent expression in all cases of necrotizing myopathy, myositis, and neuritis and expression in some cases even without these features indicate that other cytokines may be involved in muscle and nerve damage. Abnormal serum levels of several cytokines have been detected in patients with SARS$\mathrm{CoV}-2$ such as type 1 and gamma interferons, interleukin- 1 and -6 , and tumor necrosis factor- $\alpha$, among others. ${ }^{2,15,35,36}$ We do not think the histopathologic findings in this study simply reflect nonspecific changes in muscle and nerve of patients with severe illness because muscle and nerve biopsies obtained from autopsies of 10 control patients revealed necrotizing myopathy in only 1 patient and no cases with myositis or neuritis.

With regard to laboratory data, we noted that the proportion of SARS-CoV-2-positive patients in our study with elevated CK was higher $(74 \%)$ than has been reported in other studies $(9 \%-33 \%) .^{1-7}$ This is likely explained by the fact that we used peak $\mathrm{CK}$ rather than admission $\mathrm{CK}$ levels, and our cohort comprised patients with more severe COVID-19. Higher CK levels are associated with poorer outcomes. ${ }^{37}$ It is possible that cardiac injury contributed to the elevated CK because 16 of the 20 patients with elevated peak CK levels had elevated peak high-sensitivity troponin $\mathrm{T}$ levels. However, only 3 of these patients had evidence of acute cardiac injury on pathologic examination. Troponin $\mathrm{T}$ may not be specific for cardiac damage and can be elevated in patients with myopathy without cardiac injury, ${ }^{38}$ concordant with our clinical experience.

There are limitations to this study. First, we did not perform targeted histopathologic examinations of clinically symptomatic muscle and nerve. We do not know whether psoas muscle and femoral nerve were clinically affected. Clinical information was obtained retrospectively, and documentation of neuromuscular symptoms and examinations was limited. These were extremely ill patients who ended up sedated and on ventilators. Three died in the emergency room, and 5 more died within 2 days of admission. The focus on the evaluations of these patients before intubation was stabilization. Second, due to laboratory biosafety concerns, specimens were entirely fixed in formalin for paraffin-embedded sections, and frozen tissue, which is routinely used to assess muscle histopathology, was not available, nor were plastic sections and electron microscopy for muscle and nerve. In addition, because this is a postmortem case series of patients who ultimately died of the virus, our results may not reflect the full spectrum of histopathologic findings in patients with various degrees of illness severity. Our findings may be skewed to those patients with the most severe infections. Last, as mentioned, viral RNA may have been cleared from muscle and nerve tissue before death, possibly due to a robust type 1 interferon response. 
Our observations suggest that SARS-CoV-2 is frequently associated with inflammatory cell infiltrates and MxA expression in endothelial cells in both muscle and nerve, as well as necrosis of muscle fibers and abnormal MHC-1 expression in muscle. Although we did not measure cytokine levels in blood, the histopathologic abnormalities seen in our patients suggest that these findings may be secondary to the storm of cytokine release rather than direct viral infection of these tissues. Further studies are needed to better understand the pathogenic mechanisms of myopathy and neuropathy associated with SARS-CoV-2.

\section{Acknowledgment}

The authors thank the patients and their families. They are grateful for the technical expertise provided by the Brigham and Women's Hospital autopsy staff (Michelle Siciliano, Jacob Plaisted, John Grzyb) and the staff of the histology, IHC, and neuropathology laboratories (Alyson Campbell, Mark Buchanan, Mei Zheng, Sebastian Valentin, Karen Bryan).

\section{Study Funding}

The authors report no targeted funding.

\section{Disclosure}

J. Suh, S.S. Mukerji, S.I. Collens, R.F. Padera, Jr, and G.S. Pinkus report no disclosures relevant to the manuscript; A.A. Amato served on medical advisory boards for Alexion, Sarepta, CSL Behring, Strongbridge Pharma, Argenx, Ra Pharmaceuticals, and Orphazyme and is a neurology consultant for Johnson \& Johnson (SARS-CoV-2 vaccine study). I.H. Solomon reports no disclosures relevant to the manuscript. Go to Neurology.org/ $\mathrm{N}$ for full disclosures.

\section{Publication History}

Received by Neurology February 1, 2021. Accepted in final form May 25, 2021.

\section{Appendix Authors}

\begin{tabular}{lll}
\hline Name & Location & Contribution \\
\hline $\begin{array}{ll}\text { Joome Suh, } \\
\text { MD }\end{array}$ & $\begin{array}{l}\text { Brigham and } \\
\text { Women's Hospital, } \\
\text { Boston, MA }\end{array}$ & $\begin{array}{l}\text { Drafting/revision of the manuscript } \\
\text { for content, including medical } \\
\text { writing for content; major role in } \\
\text { the acquisition of data; study } \\
\end{array}$ \\
& $\begin{array}{l}\text { concept or design; analysis or } \\
\text { interpretation of data }\end{array}$
\end{tabular}

\begin{tabular}{ll}
\hline Shibani S. & Massachusetts \\
Mukerji, MD, & General Hospital, \\
PhD & Boston
\end{tabular}

Drafting/revision of the manuscript for content, including medical writing for content; major role in the acquisition of data; analysis or interpretation of data

\begin{tabular}{lll}
\hline $\begin{array}{l}\text { Sarah I. } \\
\text { Collens, BS }\end{array}$ & $\begin{array}{l}\text { Massachusetts } \\
\text { General Hospital, } \\
\text { Boston }\end{array}$ & $\begin{array}{l}\text { Drafting/revision of the manuscript } \\
\text { for content, including medical } \\
\text { writing for content; analysis or } \\
\text { interpretation of data }\end{array}$ \\
\hline $\begin{array}{l}\text { Robert F. } \\
\text { Padera, Jr, } \\
\text { MD, PhD }\end{array}$ & $\begin{array}{l}\text { Brigham and } \\
\text { Bomen's Hospital, }\end{array}$ & $\begin{array}{l}\text { Drafting/revision of the manuscript } \\
\text { for content, including medical } \\
\text { writing for content; major role in } \\
\text { the acquisition of data; analysis or } \\
\text { interpretation of data }\end{array}$ \\
\end{tabular}

Appendix (continued)

\begin{tabular}{lll}
\hline Name & Location & Contribution \\
\hline $\begin{array}{l}\text { Geraldine S. } \\
\text { Pinkus, MD }\end{array}$ & $\begin{array}{l}\text { Brigham and } \\
\text { Women's Hospital, } \\
\text { Boston, MA }\end{array}$ & $\begin{array}{l}\text { Drafting/revision of the manuscript } \\
\text { for content, including medical } \\
\text { writing for content; major role in } \\
\text { the acquisition of data }\end{array}$ \\
\hline $\begin{array}{l}\text { Anthony A. } \\
\text { Amato, MD }\end{array}$ & $\begin{array}{l}\text { Brigham and } \\
\text { Women's Hospital, } \\
\text { Boston, MA }\end{array}$ & $\begin{array}{l}\text { Drafting/revision of the manuscript } \\
\text { for content, including medical } \\
\text { writing for content; major role in } \\
\text { the acquisition of data; study } \\
\text { concept or design; analysis or } \\
\text { interpretation of data }\end{array}$ \\
$\begin{array}{lll}\text { Isaac H. } \\
\text { Solomon, MD, } \\
\text { PhD }\end{array}$ & $\begin{array}{l}\text { Brigham and } \\
\text { Bomen's Hospital, }\end{array}$ & $\begin{array}{l}\text { Drafting/revision of the manuscript } \\
\text { for content, including medical } \\
\text { writing for content; major role in } \\
\text { the acquisition of data; study } \\
\text { concept or design; analysis or } \\
\text { interpretation of data }\end{array}$ \\
& $\begin{array}{l}\text { Boston, } \\
\end{array}$ &
\end{tabular}

\section{References}

1. Romero-Sanchez CM, Diaz-Maroto I, Fernandez-Diaz E, et al. Neurologic manifestations in hospitalized patients with COVID-19: the ALBACOVID registry. Neurology. 2020;95(8):e1060-e1070.

2. Huang C, Wang Y, Li X, et al. Clinical features of patients infected with 2019 novel coronavirus in Wuhan, China. Lancet. 2020;395(10223):497-506.

3. Chen N, Zhou M, Dong X, et al. Epidemiological and clinical characteristics of 99 cases of 2019 novel coronavirus pneumonia in Wuhan, China: a descriptive study. Lancet. 2020;395(10223):507-513.

4. Mao L, Jin H, Wang M, et al. Neurologic manifestations of hospitalized patients with coronavirus disease 2019 in Wuhan, China. JAMA Neurol. 2020;77(6):683-690.

5. Li LQ, Huang T, Wang YQ, et al. COVID-19 patients' clinical characteristics, discharge rate, and fatality rate of meta-analysis. J Med Virol. 2020;92(6):577-583.

6. Borges do Nascimento IJ, Cacic N, Abdulazeem HM, et al. Novel coronavirus infection (COVID-19) in humans: a scoping review and meta-analysis. J Clin Med. 2020;9(4):941.

7. Wang D, Hu B, Hu C, et al. Clinical characteristics of 138 hospitalized patients with 2019 novel coronavirus-infected pneumonia in Wuhan, China. JAMA. 2020;323(11): 1061-1069.

8. Chedid NR, Udit S, Solhjou Z, Patanwala MY, Sheridan AM, Barkoudah E. COVID19 and rhabdomyolysis. J Gen Intern Med. 2020;35(10):3087-3090.

9. Valente-Acosta B, Moreno-Sanchez F, Fueyo-Rodriguez O, Palomar-Lever A. Rhabdomyolysis as an initial presentation in a patient diagnosed with COVID-19. BMJ Case Rep. 2020;13(6):e236719.

10. Jin M, Tong Q. Rhabdomyolysis as potential late complication associated with COVID-19. Emerg Infect Dis. 2020;26(7):1618-1620.

11. Suwanwongse K, Shabarek N. Rhabdomyolysis as a presentation of 2019 novel coronavirus disease. Cureus 2020;12(4):e7561.

12. Guan WJ, Ni ZY, Hu Y, et al. Clinical characteristics of coronavirus disease 2019 in China. N Engl J Med. 2020;382:1708-1720.

13. Zhang H, Charmchi Z, Seidman RJ, Anziska Y, Velayudhan V, Perk J. COVID-19associated myositis with severe proximal and bulbar weakness. Muscle Nerve. 2020, 62(3):E57-E60.

14. Duarte-Neto AMR, da Ssilva L, Malheiros D, et al. Pulmonary and systemic involvement in COVID-19 patients assessed with ultrasound-guided minimally invasive autopsy. Histopathology. 2020;77(2):186-197.

15. Manzano GS, Woods JK, Amato AA. Covid-19-associated myopathy caused by type I interferonopathy. N Engl J Med. 2020;383(24):2389-2390.

16. Finsterer J, Scorza FA, Ghosh R. COVID-19 polyradiculitis in 24 patients without SARS-CoV-2 in the cerebro-spinal fluid. J Med Virol. 2020;93(1):66-68.

17. Toscano G, Palmerini F, Ravaglia $S$, et al. Guillain-Barré syndrome associated with SARS-CoV-2. N Engl J Med. 2020;382(26):2574-2576.

18. Caress JB, Castoro RJ, Simmons Z, et al. COVID-19-associated Guillain-Barré syndrome: the early pandemic experience. Muscle Nerve. 2020;62(4):485-491.

19. Frontera JA, Sabadia S, Lalchan R, et al. A prospective study of neurologic disorders in hospitalized COVID-19 patients in New York City. Neurology. 2020;96(4): e575-e586.

20. Uncini A, Vallat JM, Jacobs BC. Guillain-Barré syndrome in SARS-CoV-2 infection: an instant systematic review of the first six months of pandemic. J Neurol Neurosurg Psychiatry. 2020;91(10):1105-1110.

21. Abu-Rumeileh S, Abdelhak A, Foschi M, Tumani H, Otto M. Guillain-Barre syndrome spectrum associated with COVID-19: an up-to-date systematic review of 73 cases. J Neurol. 2020;268(4):1133-1170.

22. Zhou P, Yang XL, Wang XG, et al. A pneumonia outbreak associated with a new coronavirus of probable bat origin. Nature. 2020;579(7798):270-273. 
23. Lu R, Zhao X, Li J, et al. Genomic characterisation and epidemiology of 2019 novel coronavirus: implications for virus origins and receptor binding. Lancet. 2020; 395(10224):565-574.

24. Shi Z, de Vries H, Vlaar A, et al. Diaphragm pathology in critically ill patients with COVID-19 and postmortem findings from 3 medical centers. JAMA. 2020;181(1): 122-124.

25. Cabanes-Martinez L, Villadoniga M, Gonzalez-Rodriguez L, et al. Neuromuscular involvement in COVID-19 critically ill patients. Clin Neurophysiol. 2020;131(12): 2809-2816.

26. Leung TW, Wong KS, Hui AC, et al. Myopathic changes associated with severe acute respiratory syndrome: a postmortem case series. Arch Neurol. 2005;62(7):1113-1117.

27. Ding $\mathrm{Y}$, Wang $\mathrm{H}$, Shen $\mathrm{H}$, et al. The clinical pathology of severe acute respiratory syndrome (SARS): a report from China. J Pathol. 2003;200(3):282-289.

28. Ding $\mathrm{Y}, \mathrm{He} \mathrm{L}$, Zhang $\mathrm{Q}$, et al. Organ distribution of severe acute respiratory syndrome (SARS) associated coronavirus (SARS-CoV) in SARS patients: implications for pathogenesis and virus transmission pathways. J Pathol. 2004;203(2):622-630.

29. Alsaad KO, Hajeer AH, Al Balwi M, et al. Histopathology of Middle East respiratory syndrome coronavirus (MERS-CoV) infection: clinicopathological and ultrastructural study. Histopathology. 2018;72(3):516-524.

30. Younger DS, Rosoklija G, Hays AP, Trojaborg W, Latov N. Diabetic peripheral neuropathy: a clinicopathologic and immunohistochemical analysis of sural nerve biopsies. Muscle Nerve. 1996;19(6):722-727.
31. Dubey D, David WS, Amato AA, et al. Varied phenotypes and management of immune checkpoint inhibitor-associated neuropathies. Neurology. 2019;93(11):e1093-e1103.

32. Matschke J, Lütgehetmann M, Hagel C, et al. Neuropathology of patients with COVID19 in Germany: a post-mortem case series. Lancet Neurol. 2020;19(11):919-929.

33. Aschoff R, Zimmermann N, Beissert S, Günther C. Type I interferon signature in chilblain-like lesions associated with the COVID-19 pandemic. Dermatopathology. 2020;7(3):57-63.

34. Magro CM, Mulvey JJ, Laurence J, et al. The differing pathophysiologies that underlie COVID-19-associated perniosis and thrombotic retiform purpura: a case series. $\mathrm{Br}$ Dermatol. 2021;184(1):141-150.

35. Costela-Ruiz VJ, Illescas-Montes R, Puerta-Puerta JM, Ruiz C, Melguizo-Rodriguez L. SARS-CoV-2 infection: the role of cytokines in COVID-19 disease. Cytokine Growth Factor Rev. 2020;54:62-75.

36. Pulia MS, O’Brien TP, Hou PC, Schuman A, Sambursky R. Multi-tiered screening and diagnosis strategy for COVID-19: a model for sustainable testing capacity in response to pandemic. Ann Med. 2020;52(5):207-214.

37. Zhou F, Yu T, Du R, et al. Clinical course and risk factors for mortality of adult inpatients with COVID-19 in Wuhan, China: a retrospective cohort study. Lancet. 2020;395(10229):1054-1062.

38. Jaffe AS, Vasile VC, Milone M, Saenger AK, Olson KN, Apple FS. Diseased skeletal muscle: a noncardiac source of increased circulating concentrations of cardiac troponin T. J Am Coll Cardiol. 2011;58(17):1819-1824. 


\section{Neurology}

Skeletal Muscle and Peripheral Nerve Histopathology in COVID-19 Joome Suh, Shibani S. Mukerji, Sarah I. Collens, et al.

Neurology 2021;97;e849-e858 Published Online before print June 7, 2021

DOI 10.1212/WNL.0000000000012344

This information is current as of June 7, 2021

\section{Updated Information \&} Services

\section{References}

Citations

Subspecialty Collections

Permissions \& Licensing

\section{Reprints}

including high resolution figures, can be found at: http://n.neurology.org/content/97/8/e849.full

This article cites 38 articles, 4 of which you can access for free at: http://n.neurology.org/content/97/8/e849.full\#ref-list-1

This article has been cited by 2 HighWire-hosted articles: http://n.neurology.org/content/97/8/e849.full\#\#otherarticles

This article, along with others on similar topics, appears in the following collection(s):

\section{Class IV}

http://n.neurology.org/cgi/collection/class_iv

COVID-19

http://n.neurology.org/cgi/collection/covid_19

Muscle disease

http://n.neurology.org/cgi/collection/muscle_disease

Peripheral neuropathy

http://n.neurology.org/cgi/collection/peripheral_neuropathy

Information about reproducing this article in parts (figures,tables) or in its entirety can be found online at:

http://www.neurology.org/about/about_the_journal\#permissions

Information about ordering reprints can be found online:

http://n.neurology.org/subscribers/advertise

Neurology ${ }^{\circledR}$ is the official journal of the American Academy of Neurology. Published continuously since 1951, it is now a weekly with 48 issues per year. Copyright () 2021 American Academy of Neurology. All rights reserved. Print ISSN: 0028-3878. Online ISSN: 1526-632X.

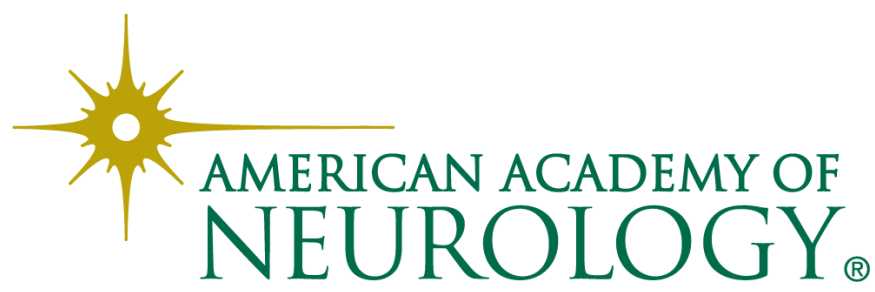

